\title{
METABOLIC ADAPTATIONS TO PROLONGED FOOD DEPRIVATION BY THE AMERICAN BADGER TAXIDEA TAXUS ${ }^{1}$
}

\author{
HENRY J. HARLOW \\ Department of Zoology and Physiology, University of Wyoming, Laramie, Wyoming 82071 \\ (Accepted 10/11/80)

\begin{abstract}
Energy expenditures for food processing, maintenance, and activity requirements were determined in the laboratory on the American badger, Taxidea taxus, both with ad lib. food and starved for 7, 20, and 30 days. Body weight decreased at about $76 \mathrm{~g}$ per day, resulting in a respiratory quotient (RQ) of 0.83 after 30 days of starvation. Energy requirements were calculated from $\dot{\mathrm{V}}_{2}$ values. A $24.2 \%, 19.7 \%$, and $26.3 \%$ reduction in total metabolism was observed at 7, 20, and 30 days, respectively, without food because of reduced maintenance and activity requirements. As a result, badgers were able to conserve approximately $17 \mathrm{~g}$ of tissue per day after 30 days without food. Part of the lower maintenance metabolism was accounted for by a $1.7 \mathrm{C}$ reduction in body temperature. Activity was most depressed the first week of starvation but progressively increased after 20 and 30 days without food.
\end{abstract}

\section{INTRODUCTION}

The effects of caloric restriction on activity and metabolism have not been investigated on wild animals which are seasonally subjected to food scarcity. The American badger, Taxidea taxus, is a solitary carnivore with opportunistic feeding habits (Errington 1937; Jense 1968; Lindzey 1971). In addition, it is found at northern latitudes where severe cold winters and reduced food availability are common (Long 1972; Lampe 1976). Starvation quickly becomes critical at low air temperatures because metabolic requirements for thermoregulation are high. Metabolic changes during starvation which reduce energy requirements would, therefore, be advantageous to winter survival.

Total metabolic requirements of an animal are expressed as the sum of ex-

1 This study was made in partial fulfillment of the requirements for a $\mathrm{Ph} . \mathrm{D}$. degree at the University of Wyoming. I would like to express sincere thanks to Harold Bergman, Jack Turner, Richard Guenzel, and Maryanne Harlow for their comments and criticisms of this manuscript. Research was supported by a University of Wyoming basic research grant and by National Science Foundation grant DEB 76-21414.

Physiol. Zool. 54(3):276-284. 1981.

(c) 1981 by The University of Chicago. 0031-935X/ 81/5403-8070\$02.00 penditures for: (1) maintenance requirements, (2) activity, (3) thermoregulation, and (4) food processing. A lower metabolism for all components except the last is considered to be adaptive during starvation (Westerterp 1978). The cost of food processing results from digestion, absorption, and assimilation of food and is referred to as the specific dynamic action (SDA) of food breakdown (Kleiber 1975). Metabolic requirements of a starving animal will, therefore, be reduced simply because the animal does not process ingested food. This reduction affords no benefit to the animal and, thus, is not adaptive. An additional nonadaptive decrease in maintenance metabolism during a fast may be due to a decreasing body mass. Many studies have claimed that the decrease in maintenance metabolism during fasting is accounted for solely by the reduced body mass and energy for processing food. Therefore, the question arises: Are there additional components of the badger's total metabolism which undergo adaptive changes during food deprivation? The present study addresses this question by examining individual changes in maintenance, activity, and thermoregulatory metabolism of badgers at various times during a 30-day fast. 


\section{MATERIAL AND METHODS}

Badgers were collected from Albany County, Wyoming, during 1977-1978 and maintained in $100-\mathrm{cm}$ square steel cages. Only adult female badgers averaging $9.7 \mathrm{~kg}$ were used in this study. They were fed Purina Dog Chow consisting of $21 \%$ crude protein, $8 \%$ fat, and $4.5 \%$ fiber and having a gross energy content of $5.15 \mathrm{kcal} / \mathrm{g}$. The study was conducted in a room exposed to ambient photoperiod changes. Body weights were measured in postabsorptive animals to minimize error from nonmetabolized food and feces in the intestinal tract.

Energy release was derived from oxygen consumption $\left(\dot{\mathrm{V}}_{\mathrm{O}_{2}}\right)$ and the estimated heat of production (corresponding to RQ [respiratory quotient] values) during starvation. An 80-cm-long, 20-cm-diameter respirometer was constructed and sealed with an airtight lid. Oxygen consumption and carbon dioxide production were derived from compositional changes of a measured flow of air through the respirometer. Air, previously scrubbed of $\mathrm{CO}^{2}$ and water, was drawn through the respirometer. Flow rate was measured with a Datametrics model 800 -L hot wire anemometer and maintained at about 6 liters/ min through the chamber. A portion of this air was channeled to either pass through or bypass a potassium hydroxide column so that the effluent air from the respirometer could either contain $\mathrm{CO}_{2}$ or be $\mathrm{CO}_{2}$-free before entering a Beckman M-3 paramagnetic oxygen analyzer (fig. 1). The presence of $\mathrm{CO}_{2}$ in a gas sample diluted the $\mathrm{O}_{2}$, thereby lowering its value in direct proportion to the $\mathrm{CO}_{2}$ concentration. Carbon dioxide was, therefore, determined on the oxygen analyzer by measuring the difference in the $\mathrm{O}_{2}$ reading of air with and without $\mathrm{CO}_{2}$. Oxygen concentration of air leaving the chamber was determined by measuring the area beneath the curve with a planimeter. Oxygen consumption was calculated from formula number 10 of Depocas and Hart (1957).

Maintenance metabolism was determined during postabsorptive, inactive periods. The total metabolism was calculated from the sum of maintenance, activity, and digestive metabolic requirements over an extended period of time. Badgers were removed from their cages during the prestarvation period and after 7, 20, and 30 days of starvation and placed into the respirometer for $\dot{\mathrm{V}}_{\mathrm{O}}$, determination. Oxygen consumption was recorded between 1800 and 2200 hours MST after $8 \mathrm{~h}$ of habituation to the chamber. A qualitative measure of activity was obtained by counting the number of times $\dot{\mathrm{V}}_{\mathrm{O}_{2}}$ rose above the resting level during this 4 -h period. In addition, a quantitative measure of activity was obtained by measuring the area of these curves above the resting level and calculating the corresponding $\dot{\mathrm{V}}_{\mathrm{O}_{2}}$. In this way total metabolism during a 4-h test period could be divided into digestive, maintenance, and activity metabolism. These energy requirements were compared during different stages of food deprivation.

The metabolic increase resulting from food intake was determined on animals previously fasted for $10 \mathrm{~h}$ to insure a postabsorptive condition prior to the $\dot{\mathrm{V}}_{\mathrm{O}_{2}}$ measurement. Badgers were then fed and $\dot{\mathrm{V}}_{\mathrm{O}_{2}}$ measured again at $3 \mathrm{~h}$ postfeeding (the time required to reach a plateau of metabolic increase) to determine resting metabolism. The metabolism of food processing was, therefore, calculated as the difference between maintenance and resting metabolism.

Oxygen consumption was also determined for each badger at $10 \mathrm{C}$ decrements between +20 and $-40 \mathrm{C}$ during ad lib. feeding and after 20 days of starvation. Badgers were maintained for $2 \mathrm{~h}$ at each temperature in a Forma Bio-ultra cold freezer before recording oxygen consumption. The lower critical temperature $\left(T_{l c}\right)$ was determined from the intersection of the leastsquares regression lines through points representing $\dot{V}_{o}$, at ambient temperatures between +20 and $-40 \mathrm{C}$ (Welch 1978). Thermal conductance was expressed as the slope of the regression line representing $\dot{\mathrm{V}}_{\mathrm{O}_{2}}$ at temperatures below the badger's $T_{l c}$.

Means were considered to be signifi- 


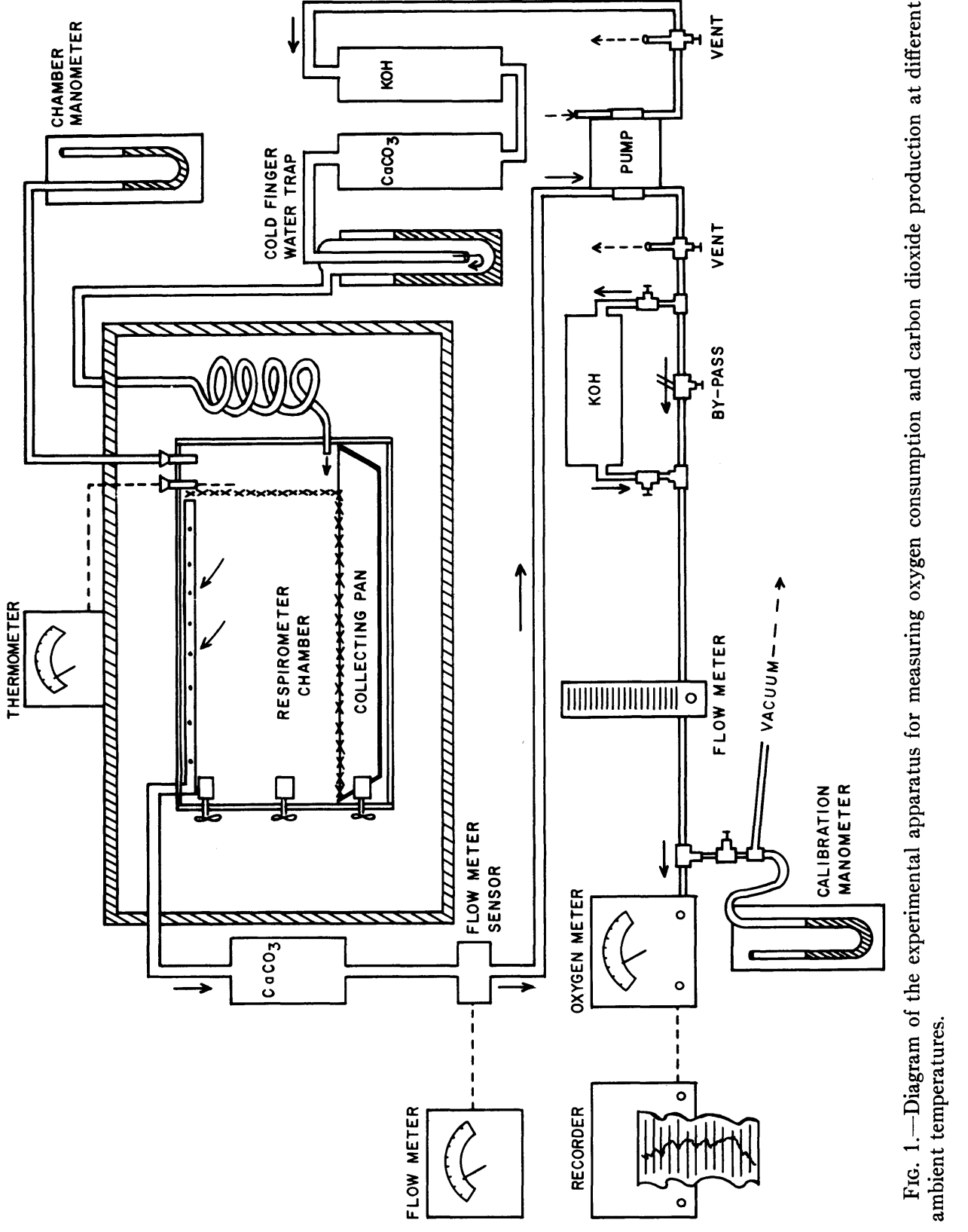


cantly different if $P<.05$ according to Student's $t$-test. Regression lines were calculated by using the least-squares method, and the difference between regression lines was tested by a $t$-test of the sum of errors of the slope (Neter and Wasserman 1974, p. 160).

\section{RESULTS}

Badgers, weighing an average of $9.7 \mathrm{~kg}$, metabolized a total of $373.6 \mathrm{kcal} /$ day under conditions of ad lib. food (table 1). During the 30-day starvation, the average body weight dropped $24 \%$, from $9.68 \mathrm{~kg}$ to $7.4 \mathrm{~kg}$ (fig. 2). A prestarvation RQ of 0.99 dropped to $0.77,0.80$, and 0.83 by days 7,20 , and 30 of starvation, respectively, indicating protein catabolism by the end of the starvation period (fig. 3). The total metabolism of badgers decreased $45 \%, 42.5 \%$, and $54 \%$ when deprived of food for 7, 20, and 30 days, respectively (table 1 ).

Approximately $19.5 \%$ of the total metabolism during feeding trials was attributed to the cost of processing food (table 1). This means that a $19.5 \%$ reduction in total metabolism was represented throughout the starvation period as a result of an empty gut (fig. 4). On days 7, 20, and 30 of starvation, the maintenance metabolism decreased $19 \%, 18 \%$, and $44 \%$ from the $243.8 \mathrm{kcal} /$ day prestarvation value (table $1)$. As a result of this reduction in maintenance metabolism, the badger's total me- tabolism was lowered $11.7 \%, 9.8 \%$, and $22 \%$ after 7,20 , and 30 days of starvation (fig. 4).

Through the early days of the starvation, there was a decrease in both the number of active bouts per hour and the percentage

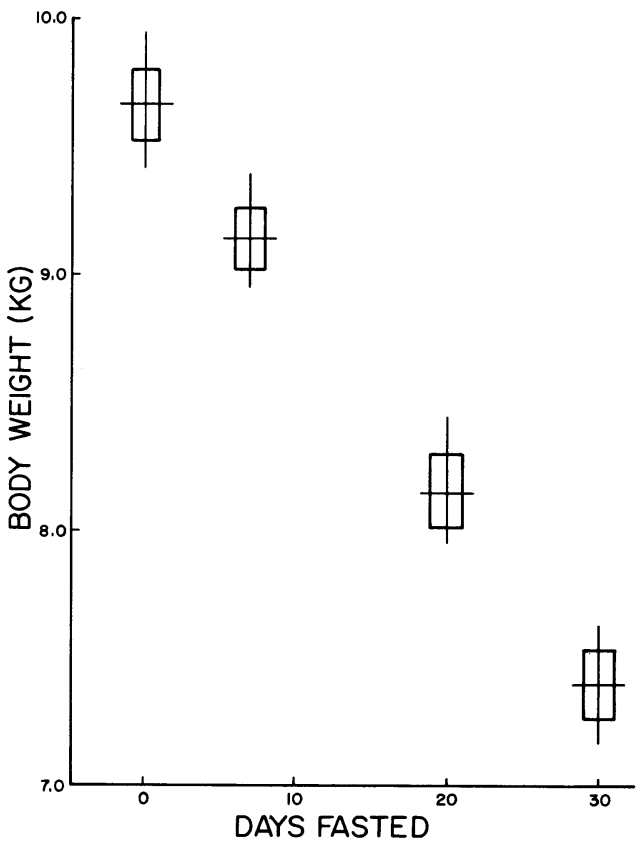

Fig. 2.-Body weight (kg) of the badger, Taxidea taxus, before fasting and at days 7,20 , and 30 of fast. Range is represented by the vertical line, mean by the horizontal line, and $2 \mathrm{SE}$ by the rectangle. No. $=6$.

TABLE 1

FOOD PROCESSING $\left(M_{\text {food-P }}\right)$, MAINTENANCE $\left(M_{\text {maint }}\right)$, ACTIVE $\left(M_{\text {act }}\right)$ AND TOTAL

$\left(M_{\text {tot }}\right)$ METABOLISM, AND \% TOTAL METABOLISM CONTRIBUTED BY FOOD PROCESSING AND ACTIVITY FOR THE BADGER "TAXIDEA TAXUS"

\begin{tabular}{|c|c|c|c|c|c|c|}
\hline Condition & $\begin{array}{c}M_{\text {food-P }} \\
\text { (kcal/Day) }\end{array}$ & $\begin{array}{c}M_{\text {maint }} \\
\text { (kcal/Day) }\end{array}$ & $\begin{array}{c}M_{\text {act }} \\
\text { (kcal/Day) }\end{array}$ & $\begin{array}{c}M_{\text {tot }} \\
(\mathrm{kcal} / \text { Day })\end{array}$ & $\begin{array}{c}\% M_{\text {tot }} \\
\text { due to } \\
M_{\text {food-P }}\end{array}$ & $\begin{array}{c}\% M_{\text {tot }} \\
\text { due to } \\
M_{\text {act }}\end{array}$ \\
\hline Fed......... & $\begin{array}{l}74.0 \\
(1.6)\end{array}$ & $\begin{array}{r}243.8 \\
(5.0)\end{array}$ & $\begin{array}{c}55.8 \\
(18.9)\end{array}$ & $\begin{array}{l}373.6 \\
(23.8)\end{array}$ & 19.5 & 14.9 \\
\hline $\begin{array}{l}\text { Starved: } \\
\quad 7 \text { days. . . . . }\end{array}$ & 0 & $\begin{array}{c}197.9 \\
(15.2)\end{array}$ & $\begin{array}{l}6.1 \\
(.4)\end{array}$ & $\begin{array}{r}203.9 \\
(15.5)\end{array}$ & 0 & 3.0 \\
\hline 20 days. . . & 0 & $\begin{array}{l}200.5 \\
(19.9)\end{array}$ & $\begin{array}{l}13.3 \\
(3.2)\end{array}$ & $\begin{array}{l}213.6 \\
(24.0)\end{array}$ & 0 & 6.1 \\
\hline 30 days. . . & 0 & $\begin{array}{l}136.3 \\
(17.4)\end{array}$ & $\begin{array}{r}35.2 \\
8.8\end{array}$ & $\begin{array}{r}171.5 \\
(14.1)\end{array}$ & 0 & 20.5 \\
\hline
\end{tabular}

NotE.-Expressed as the mean of six badgers; 2 SE shown in parentheses. 
of time active (table 2). Active metabolism on day 7 dropped $89 \%$ from the $55.8 \mathrm{kcal} /$ day prestarvation level (table 1). There was a corresponding reduction in the recorded amount of activity on day 7 , and this resulted in the lowest cost per activity over the starvation period. In addition, the contribution of activity metabolism to total metabolism dropped considerably below the $14.9 \%$ prestarvation level (table 1). Activity progressively increased through the remainder of the starvation period, however, resulting in an increased contribu-

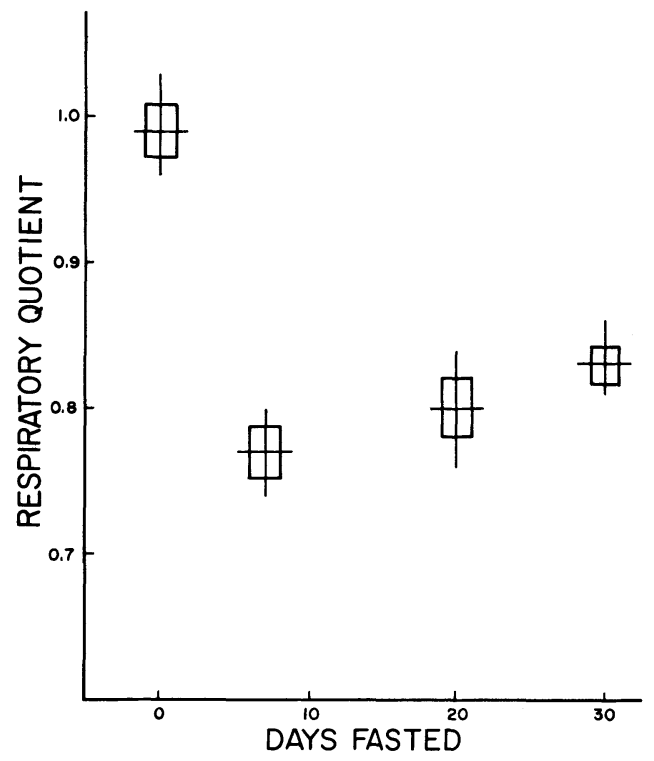

Fig. 3.-Respiratory quotient of the badger, T. taxus, before fasting and at days 7, 20, and 30 of fast. Range is represented by the vertical line, mean by the horizontal line, and $2 \mathrm{SE}$ by the rectangle. No. $=6$. tion by activity metabolism to the total metabolism (table 1) and in an increased cost per unit of activity (table 2). In spite of this, at 30 days the active metabolism was still $37 \%$ below the $55.8 \mathrm{kcal} /$ day prestarvation level (table 1). The decreased overall activity, especially in the early stages of starvation, resulted in a lower total metabolism. Reduced activity lowered the total metabolism by $12.5 \%$ on day 7 of starvation when activity was at its lowest compared to a $9.7 \%$ and $4.3 \%$ reduction on days 20 and 30, respectively, when activity was again becoming more prominent (fig. 4).

The mean rectal temperature of badgers with ad lib. food was $38.1 \mathrm{C}$, which fell to 36.7 and $36.4 \mathrm{C}$ after 20 and 30 days without food (fig. 5). At ambient temperatures above the $T_{l c}$, the total metabolism of fasted badgers was more than $40 \%$ below that of fed animals (fig. 6). At temperatures below $-20 \mathrm{C}$, however, the total metabolism for fasted badgers was significantly $(P<.005)$ higher than when they had been fed. The slope of the regression line through temperatures below the $T_{l c}$ was increased from .0123 for badgers when fed to .0169 when they had been fasted 20 days (fig. 6). These regressions were not significantly different at the $P<$ .05 level. Despite this, the small change in conductance, as a result of 20 days of starvation, did appear to shift the $T_{l c}$ from 10 to $16 \mathrm{C}$ (fig. 6).

\section{DISCUSSION}

At the end of 30 days of starvation, activity metabolism was reduced $37 \%$ and

TABLE 2

NUMBER OF ACTIVITY UNITS PER HOUR, \% TIME SPENT ACTIVE AND KCAL PER ACTIVITY UNIT FOR THE BADGER "TAXIDEA TAXUS"

\begin{tabular}{cccc}
\hline \hline Condition & $\begin{array}{c}\text { No. Activity } \\
\text { Units per Hour }\end{array}$ & $\begin{array}{c}\text { \% Time } \\
\text { Spent Active }\end{array}$ & $\begin{array}{c}\text { kcal per } \\
\text { Activity Unit }\end{array}$ \\
\hline $\begin{array}{l}\text { Fed... } \ldots \ldots \ldots \\
\text { Starved: }\end{array}$ & $1.8(.3)$ & $30.1(7.4)$ & $1.3(.2)$ \\
7 days........ & $1.0(.1)$ & $14.0(2.5)$ & $0.3(.02)$ \\
20 days....... & $0.8(.1)$ & $10.1(3.5)$ & $0.8(.1)$ \\
30 days...... & $1.4(.2)$ & $27.3(1.4)$ & $1.0(.2)$ \\
\hline
\end{tabular}

NotE.-Expressed as the mean of six badgers; 2 SE shown in parentheses. 
maintenance metabolism $44 \%$, resulting in a $26 \%$ reduction in the badger's total metabolism. Assuming that the primary tissue catabolized at the end of 30 days of starvation is protein $(\mathrm{RQ}=.83)$, this reduced metabolism represents a savings of about $17 \mathrm{~g}$ of tissue per day $(5.7 \mathrm{kcal} / \mathrm{g}$ protein). Therefore, the observed reduction in activity and basal metabolic require- ments can be considered adaptive because it conserves energy stores, thereby increasing the badger's chances for survival during winter food shortage.

The badger decreased its maintenance metabolism with body weight loss during starvation. This decreased metabolism may be a result of reduced muscle protein turnover (Waterlow and Stephen 1968),

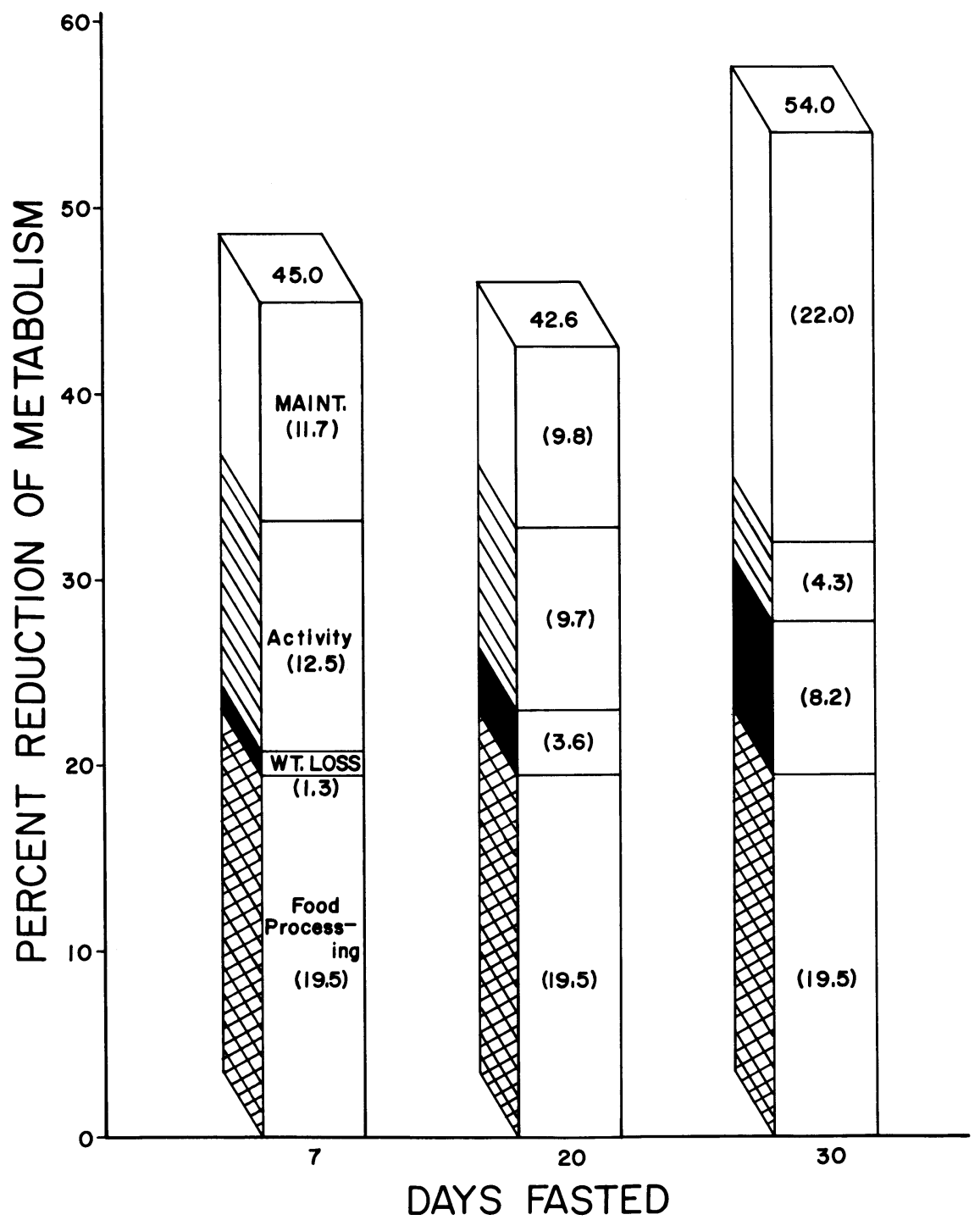

Fig. 4.-Contribution of reduced activity, maintenance metabolism, weight loss, and cessation of food processing to the reduction in total metabolism by the badger, T.taxus, at days 7,20 , and 30 of fast. No. $=6$. 
reduced maintenance of electrochemical gradients (Milligan 1971), and a lower body temperature (McCance and Mount 1969). The body temperature of badgers dropped an average of $1.7 \mathrm{C}$ by the end of 30 days without food. If we assume a temperature coefficient $\left(\mathrm{Q}_{10}\right)$ of 2.0 (Harlow $1979)$, about $15 \%$ of the reduction in maintenance metabolism was attributed to the decline in body temperature (Taylor and Keys 1950). Therefore, the badger could adapt to periods of food deprivation by lowering its thermoregulatory "set point." This would reduce heat loss and thereby conserve energy.

Laboratory studies measuring changes in activity metabolism of animals during starvation tend to be contradictory. There is some evidence suggesting an increase in activity metabolism during starvation in rats (Hitchcock 1928; Wald and Jackson 1944; Richter and Rice 1954; Bolles 1965), while other studies have shown that rats

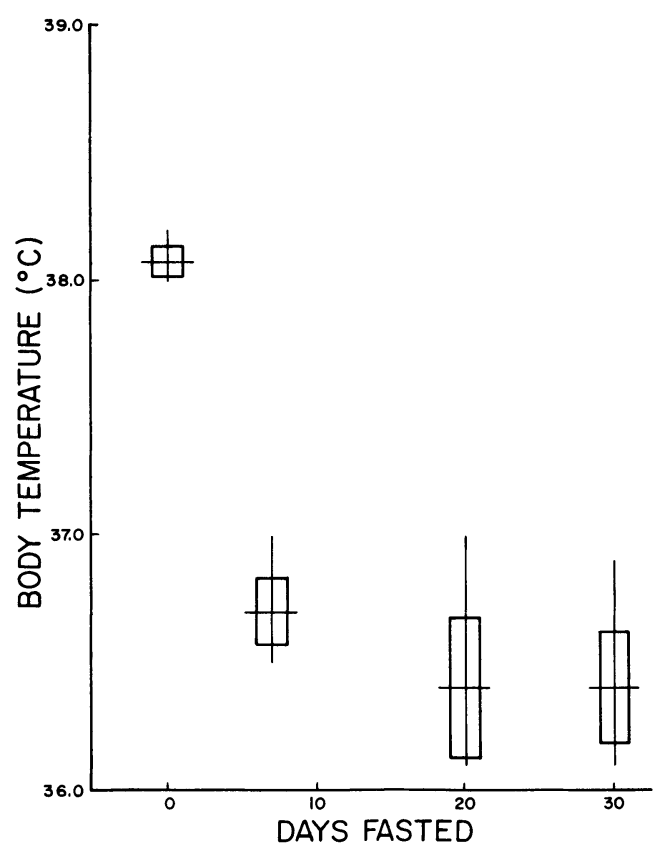

Fig. 5.-Body temperature $\left({ }^{\circ} \mathrm{C}\right)$ of the badger, $T$. taxus, before fasting and at days 7,20 , and 30 of fast. Range is represented by the vertical line, mean by the horizontal line, and 2 SE by the rectangle. No. $=6$.

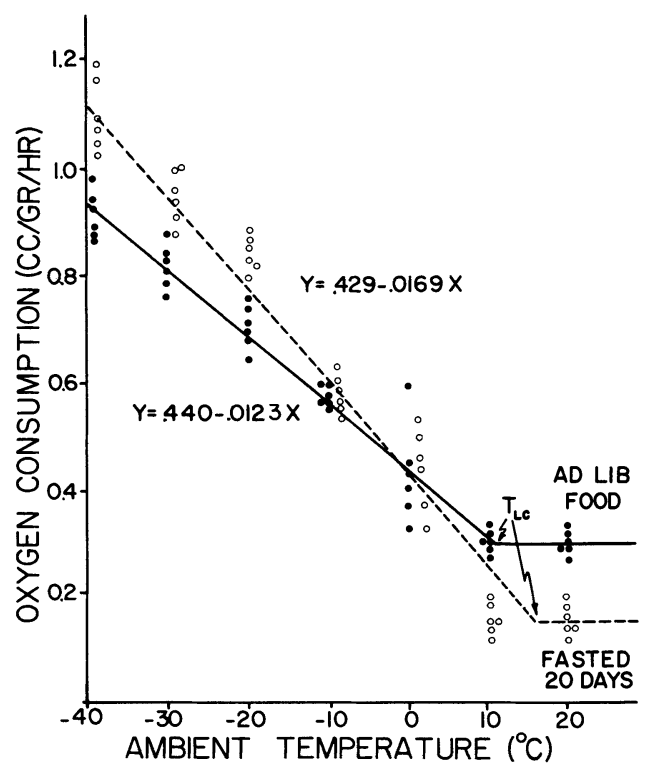

Fig. 6. - The relation of standard oxygen consumption $\left(\mathrm{cm}^{3} / \mathrm{g} / \mathrm{h}\right)$ to ambient temperatures between +20 and $-40 \mathrm{C}$ for the badger, T. taxus, during ad lib. feeding and while fasted for 30 days. Circles represent fed badgers, and triangles represent fasted badgers. The regression lines were fitted by the method of least squares. No. $=6$.

either reduce their activity metabolism or show no change from prestarvation levels (Taylor and Keys 1950; Cumming and Morrison 1960; Morrison 1968; Westerterp 1978). In the present study, starvation caused a decrease in the amount of activity and a lowering of the cost per unit of activity by badgers. Of course, activity as measured in this study does not represent the magnitude expected in a free-ranging badger. However, the amount of time and energy partitioned for activity and maintenance metabolism by animals in this study may be used as an indicator of the badger's behavior under more natural conditions.

At ambient temperatures below $-20 \mathrm{C}$, badgers when fasted did not have i lower metabolic rate than when fed. This may be a result of several factors. First, at temperatures below an animal's $T_{l c}$, the calorigenic effect of ingested food decreases in proportion to the decrease in ambient temperature (Kleiber 1975). The extent of the reduction in metabolism as a function 
of the elimination of SDA would, therefore, be diminished as the animal experienced ambient temperatures below its thermal neutral zone. Second, fat becomes the primary fuel metabolized during cold exposure (Ferguson and Folk 1971). If more fat is metabolized at colder temperatures, the high caloric content of this tissue would contribute to an increase in metabolism by fasted compared with fed badgers. In addition, catabolism of subcutaneous fat during prolonged food deprivation may result in reducing thermal insulation in these animals. The relatively steeper slope of the metabolic curve at temperatures below the $T_{l c}$ for fasted badgers may suggest that they have a reduced insulation compared with fed badgers. A higher metabolism would, therefore, be expected of starving badgers at cold temperatures so that they can compensate for the additional body heat loss. It is also possible that blood flow patterns of fed and fasted badgers respond differently to cold exposure, resulting in a different heat content for the two states. These parameters, acting alone or in concert with each other, may result in the badger's being less adapted to cold temperature when deprived of food.

The strategy for survival by badgers during the winter may, therefore, vary depending on the animal's physical state and the environmental conditions. For example, when the badger faces both low ambient temperatures and food scarcity, it gambles when hunting for food. If climatic conditions are too severe, the energy loss from increased activity and thermoregulation may outweigh any gain obtained from finding food. In this case, a reduction in activity would be the better strategy. In some parts of the badger's range, such as Wyoming, sudden temperature drops during the winter are frequent but usually last only several days. Under these conditions, it would be adaptive for the badger to maintain a low activity profile within its burrow. The advantage obtained from the thermal buffering in the burrow may outweigh the risk of actively seeking food during the transient cold stress periods. This advantage, however, may gradually be lost as body fat stores deplete and the need for caloric intake becomes strongerwhich is supported by the observed increase in activity by badgers in this study after 20 days without food. At this time the survival benefit of using the remaining energy reserves for the chance of finding food may favor increased activity.

\section{LITERATURE CITED}

Bolles, R. C. 1965. Effect of deprivation conditions upon the rat's home cage behavior. J. Comp. Physiol. Psychol. 60:244-248.

Cumming, M. C., and S. D. Morrison. 1960. The total metabolism of rats during fasting and refeeding. J. Physiol. $154: 219-243$.

Depocas, J., and J. S. Hart. 1957. Use of the Pauling oxygen analyzer for measurement of oxygen consumption in open-circuit systems and in short-lag, closed-circuit apparatus. J. Appl. Physiol. 10:388-393.

ERrington, P. L. 1937. Summer food habits of the badger in northern Iowa. J. Mammal. 18:213216.

Ferguson, J. H., and G. E. Folk. 1971. Effects of temperature and acclimation upon free fatty acid levels in three species of rodents. Can. J. Zool. 49:303-305.

Harlow, H. J. 1979. Behavioral and physiological adaptations by the American badger, Taxidea taxus, to food deprivation and cold. Ph.D. diss. University of Wyoming. $189 \mathrm{pp}$.
Hiтchсоск, F. A. 1928. The effect of low protein and protein-free diets and starvation on the voluntary activity of the albino rat. Amer. J. Physiol. 84 : 410-416.

Jense, G. K. 1968. Food habits and energy utilization of badgers. M.S. thesis. South Dakota State University, Brookings. 39 pp.

KLEIBER, M. 1975. The fire of life: an introduction to animal energetics. Revised ed. Krieger, New York. 453 pp.

LAMPE, R: 1976. Aspects of the predatory strategy of the North American badger, Taxidea taxus. Ph.D. diss. University of Minnesota at Minneapolis St. Paul. 103 pp.

Lindzey, F. G. 1971. Ecology of badgers in Curlew Valley Utah and Idaho with emphasis on movement and activity patterns. M.S. thesis. Utah State University, Logan. 50 pp.

Long, C. A. 1972. Taxonomic revision of the North American badger, Taxidea taxus. J. Mammal. 54:724-758.

McCance, R. A., and L. E. Mount. 1969. Severe 
undernutrition in growing and adult animals. Brit. J. Nutrition 14:509-518.

Milligan, L. P. 1971. Energetic efficiency and metablic transformations. Fed. Proc. 30:14541458.

Morrison, S. D. 1968. The constancy of the energy expended by rats on spontaneous activity, and the distribution of activity between feeding and non-feeding. J. Physiol. 197:305-323.

Neter, J., and W. Wasserman. 1974. Applied linear statistical models. Irwin, Homewood, Ill.

Richter, C. P., and J. K. Rice. 1954. Comparison of the effect produced by fasting on gross bodily activity of wild and domestic Norway rats. Amer. J. Physiol. 179:305-308.
TAYLOR, H. L., and A. Keys. 1950. Adaptation to caloric restriction. Science 112:215-218.

WALD, G., and B. JACKsON. 1944. The effect of starvation on activity in rats. Proc. Nat. Acad. Sci. $30: 255$.

Waterlow, J. C., and J. M. L. Stephen. 1968. The effect of low protein diets on the turnover rates of serum, liver and muscle protein in the rat measured by continuous infusion of $\mathrm{L}-\left({ }^{14} \mathrm{C}\right)$ lysine. Clin. Sci. 35:287-305.

WELCH, W. R. 1978. Fitting segmented straight lines. Wisconsin, Lab. Biophys. Ecol. Tech. Rep. 2. $15 \mathrm{pp}$.

WesterterP, K. 1978. How rats economize energy loss in starvation. Physiol. Zool. 50:331-362. 